\title{
Prioritas Strategi Pengembangan Agroindustri Manggis di Kabupaten Tasikmalaya, Jawa Barat
}

\author{
Roni Kastaman dan Ahmad Thoriq \\ Fakultas Teknologi Industri Pertanian, Universitas Padjadjaran \\ Jl. Raya Bandung-Sumedang KM 21, Jatinangor 45363 \\ *Alamat korespondensi: roni.kastaman@unpad.ac.id
}

\begin{abstract}
Priority development strategy for mangosteen agroindustry in Tasilmalaya District, West Java

Mangosteen is a fruit plant that as functional food with had many health benefits. Most mangosteen fruit was sold in the form of fresh fruit and could be processed into several products in order to increase adding value of their fruit. This study aimed to determine the potential locations, priorities and direction for mangosteen agro-industry development in Tasikmalaya Regency. Determination of potential locations was done using the Location Quotient (LQ) and Differential Shift (DS) methods, the priority determination of mangosteen agro-industry products was carried out using the exponential comparison method, mangosteen agro-industry development strategies were carried out using SWOT (Strengths, Weaknesses, Opportunities, and Threats) priorities. Mangosteen agroindustry development strategies were carried out using the Analytical Network Process (ANP). The results of the LQ and DS analysis indicated that the potential locations for mangosteen agro-industry development were found in four Sub-districts in Tasikmalaya District, namely Sodonghilir, Tanjungjaya, Sukaraja, and Jatiwaras Districts. The priority of developing mangosteen agro-industry products based on the analysis of the sequential comparative method was mangosteen peel extract (9.63), mangosteen juice (9.56), mangosteen syrup (9.53), canned mangosteen (9.51), mangosteen puree (9.50), mangosteen scalloped ice cream (9.48), mangosteen seed dodol (9.47), and mangosteen peel flour (9.45). Based on SWOT and ANP analysis, the priority of mangosteen agro-industry development strategies was obtained at farmer level, such as 1) Performing product branding and strengthen promotion, 2) Improving product quality through the application of Good Manufacturing Practice (GMP) and Cleaner Production, 3) Conducting product development and innovation, 4) Increasing quality of human resources, 5) Increasing the welfare of farmers, 6) Creating superior seeds that are able to be adaptive to the environment, and 7) Increasing the purchase price of mangosteen fruit.
\end{abstract}

Keywords: Analytical network process, Differential shift, Exponential comparison method, Location quotient, Mangosteen agro-industry

\begin{abstract}
ABSTRAK
Manggis merupakan tanaman buah yang termasuk ke dalam pangan fungsional karena memiliki banyak manfaat bagi kesehatan. Sebagian besar buah manggis dijual dalam bentuk buah segar, padahal buah manggis dapat diolah menjadi beberapa produk sehingga dapat meningkatkan nilai tambah buah manggis. Penelitian ini bertujuan menentukan lokasi potensial, prioritas dan arah pengembangan agroindustri manggis di Kabupaten Tasikmalaya. Penentuan lokasi potensial dilakukan menggunakan metode Location Quotient (LQ) and Differential Shift (DS), penentuan prioritas produk agroindustri manggis dilakukan menggunakan metode perbandingan ekponensial, strategi pengembangan agroindustri manggis dilakukan menggunakan analisis SWOT (Strengths, Weaknesses, Opportunities, and Threats) dan pemilihan prioritas strategi pengembangan agroindustri manggis dilakukan menggunakan Analytical Network Process (ANP). Hasil analisis LQ dan DS menunjukkan bahwa lokasi potensial pengembangan agroindustri manggis terdapat pada
\end{abstract}


empat Kecamatan di Kabupaten Tasikmalaya yaitu Kecamatan Sodonghilir, Tanjungjaya, Sukaraja, dan Kecamatan Jatiwaras. Prioritas pengembangan produk agroindustri manggis berdasarkan analisis metode perbandingan ekponensial secara berurutan adalah ekstrak kulit manggis $(9,63)$, sari buah/ jus manggis $(9,56)$, sirup buah manggis $(9,53)$, buah kaleng manggis $(9,51)$, puree manggis $(9,50)$, es krim kulis manggis $(9,48)$, dodol biji manggis $(9,47)$, dan tepung kulit manggis $(9,45)$. Berdasarkan analisis SWOT dan ANP diperoleh prioritas strategi pengembangan agroindustri manggis bagi petani, yakni: 1) Branding dan promosi produk, 2) Peningkatan kualitas produk melalui penerapan Good Manufacturing Practice (GMP) dan Cleaner Production, 3) Pengembangan dan inovasi produk, 4) Peningkatan kualitas sumber daya manusia, 5) Peningkatan kesejahteraan petani, 6) Bibit unggul yang mampu adaptif terhadap lingkungan, serta 7) Peningkatan harga jual buah manggis.

Kata Kunci: Agroindustri manggis, Analytical Network Process, Differential shift, Location quotient, Metode perbandingan ekponensial

\section{PENDAHULUAN}

Manggis merupakan buah unggulan ekspor Indonesia. Ekspor buah manggis pada tahun 2018 sebesar 38,84 ribu ton menjadi penyumbang devisa terbesar dari kelompok buah-buahan tahunan dengan kontribusi sebesar 55,46\% dan nilai yang mencapai US\$ 33.278.463 (BPS, 2019). Salah satu sentra produksi manggis di Indonesia adalah Kabupaten Tasikmalaya, Jawa Barat. Pada tahun 2019 produksi manggis di Kabupaten Tasikmalaya mencapai 43.272 ton (BPS Kabupaten Tasikmalaya, 2020) dan merupakan yang terbanyak dibandingkan wilayah lain di Indonesia dengan kontribusi sebesar $17,56 \%$ dari total produksi manggis nasional (BPS dan Dirjen Hortikultura, 2020). Sebagian besar buah manggis tersebut dijual dalam bentuk buah segar. Manggis dengan kualitas super (grade A), dan falcon (grade B) diekspor ke beberapa negara melalui distributor manggis (Jakiyah \& Sukmaya, 2020) sedangkan manggis dengan kualitas barang sisa (BS) atau grade $\mathrm{C}$ dijual untuk memenuhi pasar lokal atau dapat diolah menjadi beberapa produk yang dapat meningkatkan nilai tambah seperti tepung kulit, jus, cocktail, dan dodol biji manggis (Narakusuma dkk., 2013).

Buah manggis kaleng memberikan nilai tambah sebesar Rp. $18.043 / \mathrm{kg}$, tepung kulit manggis Rp. 56. 144/kg (Narakusuma, dkk., 2013), Dodol biji manggis Rp.53.677/kg, dan ekstrak kulit manggis Rp. 90.833/kg (Oryzanti et al., 2019). Beberapa produk olahan manggis tersebut terbukti bermanfaat bagi kesehatan. Minuman fungsional ekstrak kulit manggis mengandung total fenol, tanin, asam askorbat (vitamin C) dan aktivitas antioksidan (Yuarini \& Wrasiati, 2015). Ekstrak kulit manggis mampu melindungi fungsi memori dengan cara menurunkan jumlah reactive oxygen species, meningkatkan kapasitas antioksidan, mencegah apoptosis dengan cara menurunkan aktivitas caspase-3 dan meningkatkan brain derived neurotropic factor pada kultur hippocampus, mencegah terjadinya kematian sel dan melindungi fungsi sel-sel saraf (Wulan, 2015). Minuman sari buah manggis dengan perlakuan ekstraksi menggunakan blender dan perlakuan pendahuluan pengkukusan menghasilkan produk dengan nilai vitamin A 117,67 $\mu \mathrm{g} / 100 \mathrm{~g}$, karbohidrat 7,30\%, protein $0,18 \%$, serat pangan $2,21 \%$, dan energi total sebesar 32,44 kkal (Novianti dkk., 2019).

Berdasarkan beberapa hasil penelitian tersebut diperlukan perencanaan pengembangan agroindustri manggis di Kabupaten Tasikmalaya. Identifikasi lokasi potensial tanaman manggis diperlukan guna mendapatkan prioritas dan arah pengembangan agroindustri manggis. Lokasi potensial menunjukkan bahwa tanaman manggis merupakan komoditas unggulan yang memiliki keunggulan komparatif dan kompetitif dibandingkan dengan komoditas tanaman buah lainnya. Komoditas yang unggul secara komparatif memiliki nilai Location Quotient (LQ) > 1 dan komoditas yang unggul secara kompetitif memiliki nilai Differential Shift (DS) > 0 (Sitorus dkk. 2013; Nowar dkk. 2015; Keratorop dkk., 2016; Purba, 2017). Komoditas unggulan yang merupakan komoditas basis perekonomian masyarakat yang dapat dinilai dari kriteria luas areal, produktivitasnya, potensi pasar yang luas dan industri pengolahan yang memadai serta arah pertumbuhannya positif (Mulya et al., 2019). Pengembangan basis perekonomian terbukti dapat menaikkan pendapatan daerah, mengurangi pengangguran dan meningkatkan nilai ekspor produk (BI, 2019). 
Dari pengembangan agroindustri manggis akan dihasilkan beberapa produk. Penentuan prioritas pengembangan produk dapat dilakukan menggunakan metode perbandingan ekponensial (Yulianti \& Juwita, 2016; Hidayati et al., 2019). Metode Perbandingan Eksponensial (MPE) merupakan salah satu metode untuk menentukan urutan prioritas alternatif keputusan dengan kriteria jamak (Marimin, 2010).

Salah satu faktor penting dalam pengembangan usaha adalah strategi. Parameter penentuan strategi dapat dilihat dari kekuatan dan kelemahan, peluang dan ancaman (SWOT) yang berpengaruh terhadap pengembangan usaha agroindustri manggis. Menurut Namugenyi et al. (2019), SWOT dalam bisnis pertanian menawarkan solusi sederhana dan efisien untuk mengelola elemen data yang berpengaruh terhadap pengembangan usaha. Menurut Kasutjianingati et al. (2019), prioritas strategi yang dihasilkan dari analisis SWOT dapat ditentukan menggunakan metode Analytical Network Process (ANP).

Penelitian ini bertujuan menganalisis lokasi potensial tanaman manggis, menentukan prioritas dan arah pengembangan agroindustri manggis di Kabupaten Tasikmalaya, Propinsi Jawa Barat. Hasil penelitian ini diharapkan dapat dijadikan sebagai acuan bagi pemerintah daerah dalam pengembangan agroindustri manggis.

\section{BAHAN DAN METODE}

\section{Waktu dan Tempat}

Penelitian ini laksanakan pada bulan Juli hingga Desember 2019 bertempat di Kabupaten Tasikmalaya Propinsi Jawa Barat dan Fakultas Teknologi Industri Pertanian Universitas Padjadjaran.

\section{Teknik Pengumpulan Data}

Data pada penelitian ini terdiri atas data primer dan data sekunder. Data primer dikumpulkan melalui focus group discussion (FGD) dan wawancara langsung dengan tujuan untuk mendapatkan prioritas dan arah pengembangan agroindustri manggis, sedangkan data sekunder berupa data jumlah panen pohon manggis dan jumlah panen pohon buah secara keseluruhan, diperoleh dari Dinas Pertanian Kabupaten Tasikmalaya, Propinsi Jawa Barat. Data yang digunakan untuk perhitungan Location Quotient (LQ) adalah data tahun 2018 sedangkan data yang digunakan untuk perhitungan Differential Shift (DS) adalah data tahun 2013 dan 2018.

\section{Tahapan Penelitian}

Tahapan yang dilakukan pada penelitian ini secara lebih rinci dapat dilihat pada Gambar 1.

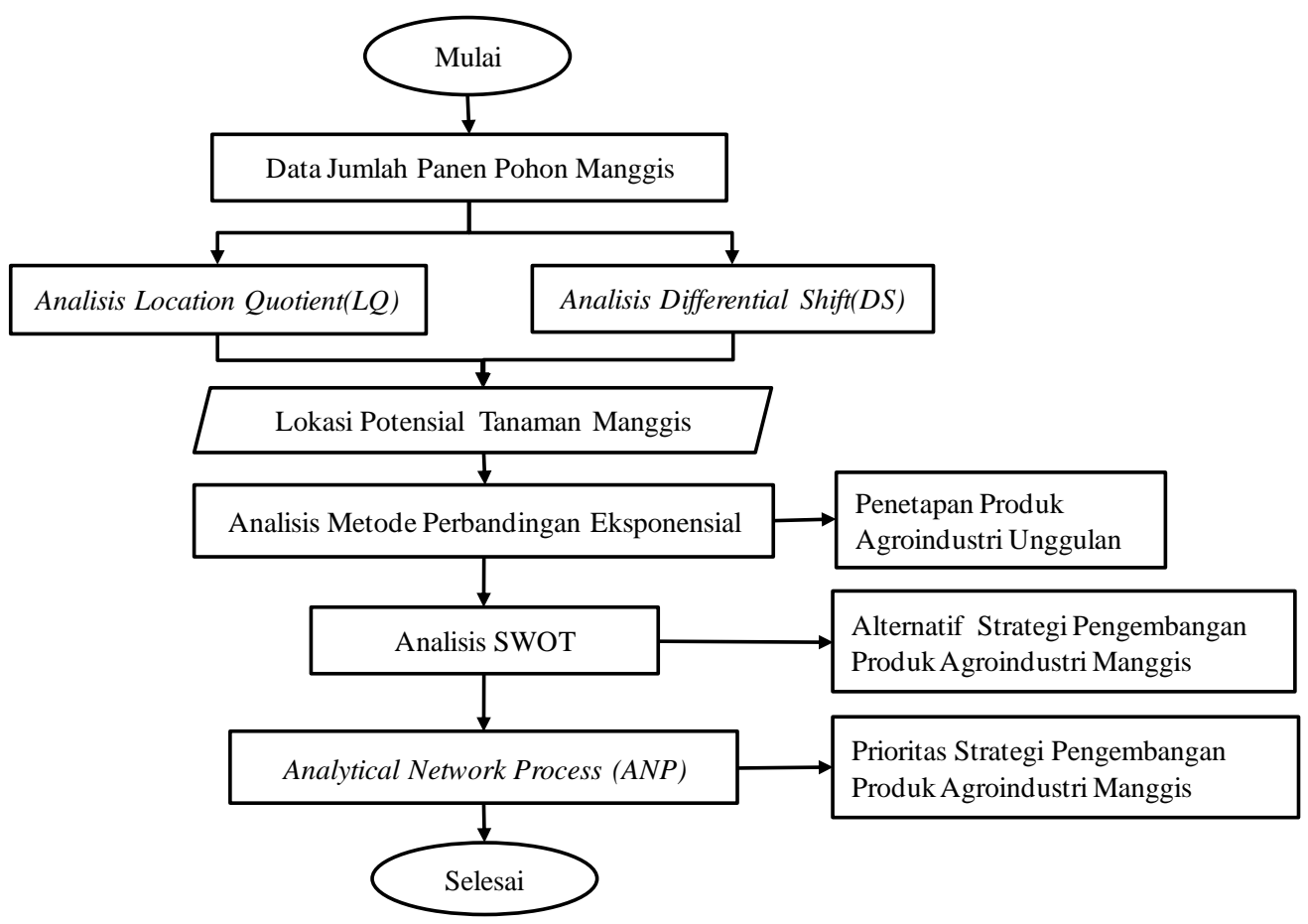

Gambar 1. Diagram alir penelitian. 


\section{Pengolahan dan Analisis Data}

\section{Analisis Location Quotient (LQ)}

Analisis LQ bertujuan menentukan lokasi potensial manggis yang unggul secara komparatif dibandingkan dengan tanaman buah lainnya. Data yang digunakan adalh jumlah panen pohon manggis dan jumlah panen tanaman buah secara keseluruhan. Hal ini disebabkan oleh karena jumlah panen merupakan resultan kesesuaian tumbuh tanaman berdasarkan kondisi agroekologi (Hendayana, 2003). Persamaan yang digunakan pada analisis LQ adalah sebagai berikut:

$$
\mathbf{L Q}=\frac{\mathbf{x}_{\mathbf{i}} / \Sigma \mathbf{x}_{\mathbf{j}}}{\sum \mathbf{Y}_{\mathbf{i}} / \Sigma \mathbf{Y}_{\mathbf{j}}}
$$

Keterangan:

LQ = Location Quotient

$\mathrm{X}_{\mathrm{i}} \quad=$ Luas panen komoditas i di Kecamatan $\mathrm{X}$

$\sum \mathrm{X}_{\mathrm{j}} \quad=$ Jumlah luas panen seluruh komoditas

tanaman buah di Kecamatan $\mathrm{X}$

$\sum \mathrm{Y}_{\mathrm{i}} \quad$ = Jumlah luas panen komoditas i di

Kabupaten Tasikmalaya

$\sum \mathrm{Y}_{\mathrm{j}} \quad$ = Jumlah luas panen seluruh komoditas tanaman buah di Kabupaten Tasikmalaya

Analisis LQ menghasilkan tiga (3) kriteria yaitu (1) LQ > 1 menunjukkan bahwa komoditas tersebut menjadi basis atau menjadi sumber pertumbuhan, (2) LQ = 1 menunjukkan bahwa komoditas itu tergolong non-basis dan tidak memiliki keunggulan komparatif, dan LQ $<1$ menunjukkan bahwa komoditas ini juga termasuk non-basis (Hendayana, 2003).

\section{Analisis Differential Shift (DS)}

Analisis DS menunjukkan tingkat kompetisi suatu komoditas tertentu dibandingkan dengan pertumbuhan total produksi komoditas tersebut pada suatu wilayah. Perhitungan DS ditentukan menggunakan persamaan berikut:

$$
\boldsymbol{D S}=\left[\frac{P_{i(t 1)}}{P_{i(t 0)}}-\frac{\sum \mathbf{B}_{\mathbf{i}}}{\sum \mathbf{B}_{\mathbf{j}}}\right]
$$

Keterangan:

DS = Differential Shift

$\mathrm{X}_{\mathrm{i}} \quad=$ Nilai luas panen komoditas $\mathrm{x} \mathrm{di}$

Kecamatan $\mathrm{P}$

$\sum \mathrm{Y}_{\mathrm{i}} \quad$ = Jumlah luas panen komoditas $\mathrm{x} \mathrm{di}$ Kabupaten Tasikmalaya $\sum \mathrm{Y}_{\mathrm{j}} \quad=$ Jumlah luas panen seluruh komoditas tanaman buah di Kabupaten Tasikmalaya

$\mathrm{t}_{1} \quad=$ Titik tahun akhir (tahun 2018)

to $\quad=$ Titik tahun awal (tahun 2013)

Analisis DS akan menghasilkan 2 (dua) kriteria yaitu DS $>0$ menunjukkan bahwa komoditas tersebut mempunyai tingkat persaingan yang tinggi, dan DS $<0$ menunjukkan bahwa komoditas yang dimaksud mempunyai tingkat persaingan yang rendah dibandingkan dengan komoditas yang lain. Suatu komoditas dinyatakan merupakan komoditas unggulan apabila memiliki nilai $\mathrm{LQ}>1$ dan nilai DS $>0$, yang menyatakan bahwa komoditas tersebut memiliki keunggulan kompetitif dan mampu bersaing dengan komoditas sejenis atau lainnya pada suatu daerah (Sitorus, dkk., 2013; Nowar, dkk., 2015; Keratorop, dkk., 2016; Purba, 2017; Mulya et al., 2019).

\section{Analisis Metode Perbandingan Eksponensial (MPE)}

MPE dilakukan untuk menetapkan prioritas pilihan pakar terhadap berbagai produk agroindustri manggis yang ditetapkan. Pakar pada penelitian ini terdiri atas 6 orang yaitu Kabid Perkebunan Kabupaten Tasikmalaya, Kabid Tanaman Pangan Dan Hortikultura Kabupaten Tasikmalaya, Kabid Ekonomi Bappeda Kabupaten Tasikmalaya, Kabid Koperasi Dan Usaha Kecil Menengah Kabupaten Tasikmalaya, Kabid Perdagangan Dan Perindustrian Kabupaten Tasikmalaya, dan akademisi bidang Teknologi Pertanian dari Universitas Padjadjaran. Menurut Marimin (2010), penghitungan total nilai setiap pilihan keputusan dapat diformulasikan sebagai berikut:

$$
M P E=\sum_{j=1}^{m}\left(R k_{i j}\right)^{T K K_{j}}
$$

\section{Keterangan:}

$\mathrm{Rk}_{\mathrm{ij}}=$ Derajat kepentingan relatif kriteria ke-j pada alternatif ke-i, yang ordinal

$\mathrm{TKK}_{\mathrm{j}}=$ Derajat kepentingan alternatif keputusan, yang dinyatakan dengan bobot

$\mathrm{n} \quad=$ Jumlah pilihan keputusan

$\mathrm{m} \quad=$ Jumlah kriteria keputusan

\section{Analisis SWOT dan ANP}

Analisis Kekuatan, Kelemahan, Peluang dan Ancaman (SWOT) dan Analytical Network Process 
(ANP) dengan langkah-langkah (Qurratu'ain, 2017) sebagai berikut:

a) Identifikasi faktor kekuatan, kelemahan, peluang dan ancaman (SWOT)

b) Analisis faktor internal dan eksternal menggunakan matriks IFE dan EFE

c) Tentukan alternative strategi menggunakan matrik SWOT

d) Identifikasi tujuan strategis

e) Bangun model Analytical Network Process (ANP) berdasarkan tujuan strategis, faktor, aktor, dan alternative strategi

f) Hitung ANP menggunakan perbandingan berpasangan antara berbagai elemen model ANP dilakukan

g) Periksa konsistensi rasio (CR) setiap matriks baik individu maupun gabungan. Bila nilai CR $<10 \%$ maka matriks dinyatakan konsisten

h) Tarik kesimpulan terhadap strategi yang terpilih

\section{HASIL DAN PEMBAHASAN}

\section{Identifikasi lokasi potensial tanaman manggis di Kabupaten Tasikmalaya}

Identifikasi lokasi potensial didasarkan pada jumlah panen pohon manggis dan jumlah panen seluruh tanaman buah tiap kecamatan di Kabupaten Tasikmalaya. Rincian jumlah panen pohon manggis dan jumlah panen seluruh tanaman buah di Kabupaten Tasikmalaya tahun 2013 dan 2018 dapat dilihat pada Tabel 1.

Data jumlah panen seluruh tanaman buah sebagaimana terdapat pada Tabel 1 merupakan penjumlahan jumlah panen 22 jenis tanaman buah yang terdapat di Kabupaten Tasikmalaya. Berdasarkan Tabel 1 terlihat bahwa jumlah panen pohon manggis terbanyak pada tahun 2018 terdapat pada Kecamatan Tanjungjaya (66.468 pohon), Kecamatan Sodonghilir (59.904 pohon) dan Kecamatan Puspahiang (40.643 pohon). Pada periode 2013 hingga 2018 terjadi pengurangan jumlah panen pohon manggis sebanyak 79.743 pohon, namun terjadi penambahan jumlah pohon manggis sebanyak 131.184 pohon. Penambahan jumlah panen pohon manggis terbanyak terdapat pada Kecamatan Tanjungjaya (43.968 pohon) dan kecamatan Sodonghilir (40.194 pohon) sedangkan pengurangan jumlah panen pohon manggis terbanyak terdapat pada kecamatan Puspahiang yang mencapai 53.634 pohon. Berdasarkan hasil wawancara, pengurangan jumlah panen pohon manggis yang terjadi di beberapa kecamatan karena program replanting, di mana beberapa pohon tua sudah tidak produktif atau terserang penyakit sehingga harus ditebang. Secara komulatif terjadi pengurangan jumlah panen tanaman buah dari 20.432.605 pohon (2013) menjadi hanya 5.132.216 pohon di tahun 2018. Pengurangan secara signifikan terjadi di Kecamatan Cineam, Kecamatan Cipatujah, Kecamatan Gunungtanjung, Kecamatan Karangjaya, dan Kecamatan Manonjaya.

Sebagian besar usaha tani manggis di Kabupaten Tasikmalaya merupakan usaha turuntemurun sehingga petani memiliki cukup pengalaman dalam melakukan usaha tani manggis. Rata-rata pengalaman petani dalam usaha tani manggis adalah lebih dari 15 tahun dengan kepemilikan lahan berkisar antara 0,5 - 1,0 hektar atau 50 - 100 pohon (Muchtaridi dkk., 2019). Meskipun demikian tanaman manggis hanya menjadi unggulan di beberapa kecamatan di Kabupaten Tasikmalaya, hal ini karena pada beberapa kecamatan tanaman manggis hanya unggul secara komparatif atau hanya unggul secara kompetitif. Hasil analisis LQ dan DS secara lebih rinci dapat dilihat pada Tabel 2.

Pada Tabel 2 terlihat bahwa lokasi potensial tanaman manggis yang menunjukkan tanaman manggis menjadi unggulan karena memiliki nilai LQ $>1$ dan DS > 0 terdapat pada 4 kecamatan yaitu Kecamatan Sodonghilir, Kecamatan Tanjungjaya, Kecamatan Sukaraja, dan Kecamatan Jatiwaras. Kecamatan Puspahiang yang memiliki jumlah panen pohon manggis sebanyak 40.643 pohon justru tidak menjadi komoditas unggulan karena tanaman manggis di Kecamatan Puspahiang hanya unggul secara basis komoditas tetapi tidak unggul secara kompetitif, yang disebabkan karena terjadinya pengurangan jumlah panen pohon manggis sebanyak 53.634 pohon pada periode 2013 hingga 2018. Meskipun demikian, terdapat delapan kecamatan yang yang unggul secara kompetitif karena memiliki nilai DS >0 yaitu Kecamatan Cikatomas, Kecamatan Cibalong, Kecamatan Parungponteng, Kecamatan Bojongasih, Kecamatan Cineam, Kecamatan Gunungtanjung, Kecamatan Cisayong, dan Kecamatan Kadipaten. Hal tersebut menunjukkan bahwa terjadi penambahan jumlah panen pohon manggis pada delapan kecamatan tersebut selama periode 2013 hingga 2018. 
Tabel 1. Jumlah panen pohon manggis dan seluruh tanaman buah tiap kecamatan di kabupaten Tasikmalaya tahun 2013 dan 2018.

\begin{tabular}{|c|c|c|c|c|c|c|}
\hline \multirow[t]{2}{*}{ No. } & \multirow[t]{2}{*}{ Kecamatan } & \multicolumn{2}{|c|}{$\begin{array}{l}\text { Jumlah panen manggis } \\
\text { (pohon) }\end{array}$} & \multirow[t]{2}{*}{ Selisih } & \multicolumn{2}{|c|}{$\begin{array}{l}\text { Jumlah panen seluruh } \\
\text { tanaman buah (pohon) }\end{array}$} \\
\hline & & 2018 & 2013 & & 2018 & 2013 \\
\hline 1. & Bantarkalong & 152 & 1.200 & -1.048 & 206.509 & 111.004 \\
\hline 2. & Bojongasih & 801 & 260 & 541 & 102.987 & 145.582 \\
\hline 3. & Bojonggambir & 1.433 & & 1.433 & 124.355 & 21.218 \\
\hline 4. & Ciawi & 5 & & 5 & 42.402 & 40.006 \\
\hline 5. & Cibalong & 2.600 & 1.400 & 1.200 & 86.301 & 44.178 \\
\hline 6. & Cigalontang & - & 22 & -22 & 8.270 & 63.387 \\
\hline 7. & Cikalong & 630 & 583 & 47 & 69.139 & 317.360 \\
\hline 8. & Cikatomas & 5.240 & 1.080 & 4.160 & 127.775 & 86.173 \\
\hline 9. & Cineam & 21 & 12 & 9 & 261.554 & 5.009 .261 \\
\hline 10. & Cipatujah & 4.850 & 5.327 & -477 & 470.695 & 1.258 .287 \\
\hline 11. & Cisayong & 20 & 10 & 10 & 15.755 & 6.919 \\
\hline 12. & Culamega & 510 & 1.077 & -567 & 356.308 & 129.286 \\
\hline 13. & Gunungtanjung & 783 & 145 & 638 & 144.665 & 2.631 .191 \\
\hline 14. & Jamanis & - & - & - & 17.396 & 14.207 \\
\hline 15. & Jatiwaras & 32.485 & 18.940 & 13.545 & 225.038 & 429.408 \\
\hline 16. & Kadipaten & 14 & 2 & 12 & 102.699 & 70.351 \\
\hline 17. & Karangjaya & - & 35 & -35 & 265.710 & 2.836 .955 \\
\hline 18. & Karangnunggal & 250 & 4.700 & -4.450 & 130.056 & 186.097 \\
\hline 19. & Leuwisari & 298 & - & 298 & 46.257 & 28.702 \\
\hline 20. & Mangunreja & - & 3.124 & -3.124 & 35.903 & 41.249 \\
\hline 21. & Manonjaya & 600 & - & 600 & 401.630 & 4.873 .762 \\
\hline 22. & Padakembang & 9 & 13 & -4 & 16.570 & 16.938 \\
\hline 23. & Pageurageung & - & - & - & 13.910 & 31.228 \\
\hline 24. & Pancatengah & - & - & - & 50.062 & 423.110 \\
\hline 25. & Parungponteng & 2.417 & 1.500 & 917 & 134.652 & 83.002 \\
\hline 26. & Puspahiang & 40.643 & 94.277 & -53.634 & 181.908 & 247.095 \\
\hline 27. & Rajapolah & 5 & - & 5 & 23.880 & 16.278 \\
\hline 28. & Salawu & 6.000 & 13.305 & -7.305 & 190.342 & 220.794 \\
\hline 29. & Salopa & 92 & 8.300 & -8.208 & 317.368 & 296.261 \\
\hline 30. & Sariwangi & 12 & - & 12 & 18.300 & 23.800 \\
\hline 31. & Singaparna & 20 & 55 & -35 & 58.358 & 66.297 \\
\hline 32. & Sodonghilir & 59.904 & 19.710 & 40.194 & 211.366 & 150.689 \\
\hline 33. & Sukahening & 8 & 17 & -9 & 11.857 & 24.726 \\
\hline 34. & Sukaraja & 28.763 & 5.173 & 23.590 & 101.923 & 57.291 \\
\hline 35. & Sukarame & - & - & - & 22.244 & 32.077 \\
\hline 36. & Sukaratu & - & - & - & 17.620 & 15.424 \\
\hline 37. & Sukaresik & - & - & - & 31.470 & 22.291 \\
\hline 38. & Tanjungjaya & 66.468 & 22.500 & 43.968 & 402.771 & 127.300 \\
\hline 39. & Taraju & 4.310 & 5.135 & -825 & 86.211 & 233.421 \\
\hline Jumla & & 259.343 & 207.902 & & 5.132 .216 & 20.432 .605 \\
\hline
\end{tabular}

Sumber: Dinas Pertanian Kabupaten Tasikmalaya, 2019.

Prioritas pengembangan produk agroindustri metode perbandingan ekponensial (MPE) dengan

\section{manggis}

Penetapan prioritas pengembangan produk agroindustri manggis dilakukan menggunakan mengacu pada beberapa kriteria penting yang terdiri atas 1) ketersediaan pasar, 2) kelestarian lingkungan, 3) ketersediaan bahan baku, 4) dukungan 
pemerintah daerah, 5) kemampuan sumber daya manusia, 6) ketersediaan teknologi, 7) kemampuan bersaing produk sejenis, dan 8) modal usaha. Masing-masing kriteria diberi bobot untuk mengetahui kriteria yang paling menentukan dalam penetapan produk agroindustri manggis. Bobot kriteria didasarkan penilaian kepentingan penilaian kriteria tersebut, dengan nilai masing -masing kriteria $1-5$. Pembobotan tersebut dilakukan oleh pakar yang sudah dipilih. Bobot masing-masing kriteria dapat dilihat pada Gambar 2.

Tabel 2. Hasil analisis LQ dan DS.

\begin{tabular}{|c|c|c|c|c|}
\hline No. & Kecamatan & LQ & DS & Keterangan \\
\hline 1. & Bantarkalong & 0,01 & $-1,12$ & \\
\hline 2. & Bojongasih & 0,15 & 1,83 & Unggul (kompetitif) \\
\hline 3. & Bojonggambir & 0,23 & TAD & \\
\hline 4. & Ciawi & 0 & TAD & \\
\hline 5. & Cibalong & 0,6 & 0,61 & Unggul (kompetitif) \\
\hline 6. & Cigalontang & 0 & $-1,25$ & \\
\hline 7. & Cikalong & 0,18 & $-0,17$ & \\
\hline 8. & Cikatomas & 0,81 & 3,6 & Unggul (kompetitif) \\
\hline 9. & Cineam & 0 & 0,5 & Unggul (kompetitif) \\
\hline 10. & Cipatujah & 0,2 & $-0,34$ & \\
\hline 11. & Cisayong & 0,03 & 0,75 & Unggul (kompetitif) \\
\hline 12. & Culamega & 0,03 & $-0,77$ & \\
\hline 13. & Gunungtanjung & 0,11 & 4,15 & Unggul (kompetitif) \\
\hline 14. & Jamanis & 0 & TAD & \\
\hline 15. & Jatiwaras & 2,86 & 0,47 & Unggulan (komparatif \& kompetitif) \\
\hline 16. & Kadipaten & 0 & 5,75 & Unggul (kompetitif) \\
\hline 17. & Karangjaya & 0 & $-1,25$ & \\
\hline 18. & Karangnunggal & 0,04 & $-1,19$ & \\
\hline 19. & Leuwisari & 0,13 & TAD & \\
\hline 20. & Mangunreja & 0 & $-1,25$ & \\
\hline 21. & Manonjaya & 0,03 & TAD & \\
\hline 22. & Padakembang & 0,01 & $-0,56$ & \\
\hline 23. & Pageurageung & 0 & TAD & \\
\hline 24. & Pancatengah & 0 & TAD & \\
\hline 25. & Parungponteng & 0,36 & 0,36 & Unggul (kompetitif) \\
\hline 26. & Puspahiang & 4,42 & $-0,82$ & Unggul (komparatif) \\
\hline 27. & Rajapolah & 0 & TAD & \\
\hline 28. & Salawu & 0,62 & $-0,8$ & \\
\hline 29. & Salopa & 0,01 & $-1,24$ & \\
\hline 30. & Sariwangi & 0,01 & NAD & \\
\hline 31. & Singaparna & 0,01 & $-0,88$ & \\
\hline 32. & Sodonghilir & 5,61 & 1,79 & Unggulan (komparatif dan kompetitif) \\
\hline 33. & Sukahening & 0,01 & $-0,78$ & \\
\hline 34. & Sukaraja & 5,58 & 4,31 & Unggulan (komparatif \& kompetitif) \\
\hline 35. & Sukarame & 0 & TAD & \\
\hline 36. & Sukaratu & 0 & TAD & \\
\hline 37. & Sukaresik & 0 & TAD & \\
\hline 38. & Tanjungjaya & 3,27 & 1,71 & Unggulan (komparatif \& kompetitif) \\
\hline 39. & Taraju & 0,99 & $-0,41$ & \\
\hline
\end{tabular}

Keterangan: $\mathrm{TAD}=$ tidak ada data.

Sumber: diolah dari Dinas Pertanian Kabupaten Tasikmalaya, 2019. 


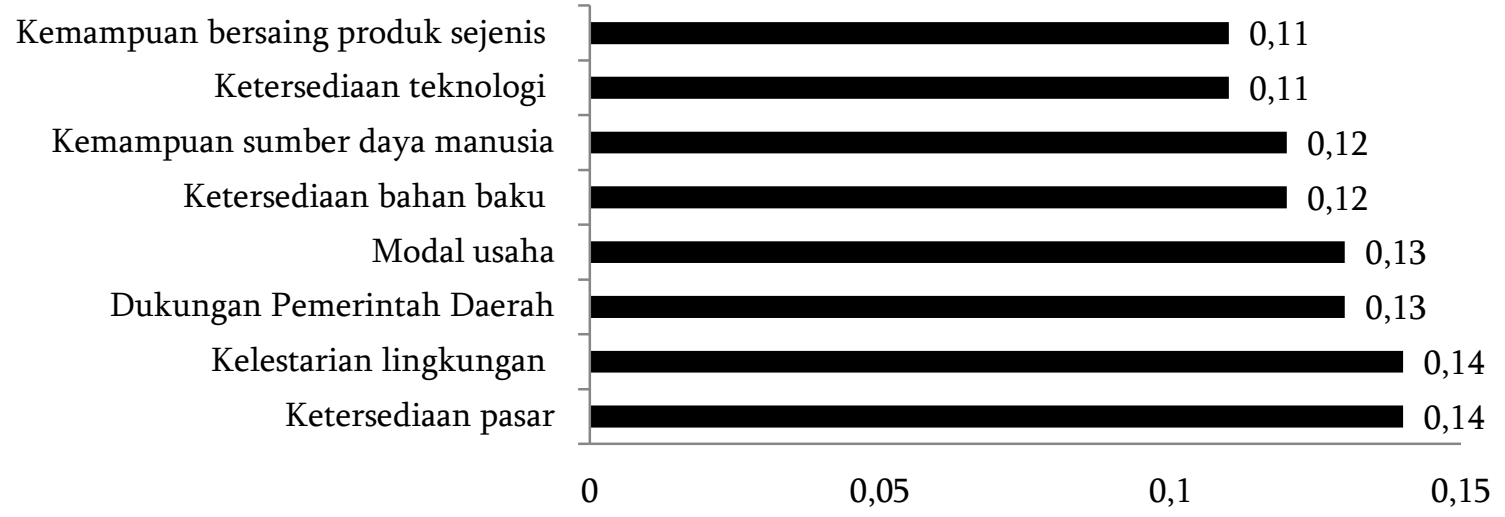

Gambar 1. Kriteria dan bobot penentuan produk agroindustri manggis.

Tabel 3. Hasil analisis MPE produk agroindustri manggis

\begin{tabular}{lcccccccc}
\hline & \multicolumn{7}{c}{ Hasil Perhitungan MPE } \\
\cline { 2 - 8 } \multicolumn{1}{c}{ Kriteria } & $\begin{array}{c}\text { Buah } \\
\text { Kaleng } \\
\text { Manggis }\end{array}$ & $\begin{array}{c}\text { Estrak } \\
\text { kulit } \\
\text { manggis }\end{array}$ & $\begin{array}{c}\text { Sirup } \\
\text { buah } \\
\text { manggis }\end{array}$ & $\begin{array}{c}\text { Sari } \\
\text { buah/ } \\
\text { jus } \\
\text { manggis }\end{array}$ & $\begin{array}{c}\text { Puree } \\
\text { manggis }\end{array}$ & $\begin{array}{c}\text { Dodol } \\
\text { biji } \\
\text { manggis }\end{array}$ & $\begin{array}{c}\text { Tepung } \\
\text { kulit } \\
\text { manggis }\end{array}$ & $\begin{array}{c}\text { Es krim } \\
\text { kulit } \\
\text { manggis }\end{array}$ \\
\hline $\begin{array}{l}\text { Ketersediaan } \\
\text { pasar }\end{array}$ & 1,21 & 1,23 & 1,23 & 1,23 & 1,21 & 1,21 & 1,21 & 1,21 \\
$\begin{array}{l}\text { Kelestarian } \\
\text { lingkungan }\end{array}$ & 1,19 & 1,19 & 1,19 & 1,19 & 1,19 & 1,19 & 1,19 & 1,19 \\
$\begin{array}{l}\text { Dukungan } \\
\text { Pemerintah }\end{array}$ & 1,22 & 1,25 & 1,22 & 1,22 & 1,22 & 1,22 & 1,22 & 1,22 \\
$\begin{array}{l}\text { Daerah } \\
\text { Modal usaha }\end{array}$ & 1,18 & 1,20 & 1,18 & 1,18 & 1,18 & 1,18 & 1,18 & 1,18 \\
$\begin{array}{l}\text { Ketersediaan } \\
\text { bahan baku }\end{array}$ & 1,28 & 1,27 & 1,28 & 1,28 & 1,28 & 1,26 & 1,26 & 1,27 \\
$\begin{array}{l}\text { Kemampuan } \\
\text { sumber } \\
\text { manusia }\end{array}$ & 1,14 & 1,16 & 1,14 & 1,14 & 1,14 & 1,14 & 1,14 & 1,14 \\
$\begin{array}{l}\text { Ketersediaan } \\
\text { teknologi }\end{array}$ & 1,11 & 1,15 & 1,13 & 1,11 & 1,11 & 1,11 & 1,11 & 1,11 \\
$\begin{array}{l}\text { Kemampuan } \\
\text { bersaing } \\
\text { produk sejenis }\end{array}$ & 1,16 & 1,16 & 1,16 & 1,16 & 1,15 & 1,15 & 1,13 & 1,15 \\
\hline $\begin{array}{l}\text { Jumlah Nilai } \\
\text { MPE }\end{array}$ & $\mathbf{9 , 4 9}$ & $\mathbf{9 , 6 2}$ & $\mathbf{9 , 5 4}$ & $\mathbf{9 , 5 1}$ & $\mathbf{9 , 4 8}$ & $\mathbf{9 , 4 6}$ & $\mathbf{9 , 4 4}$ & $\mathbf{9 , 4 7}$ \\
\hline $\begin{array}{l}\text { Urutan } \\
\text { Prioritas }\end{array}$ & $\mathbf{4}$ & $\mathbf{1}$ & $\mathbf{2}$ & $\mathbf{3}$ & $\mathbf{5}$ & $\mathbf{7}$ & $\mathbf{8}$ & $\mathbf{6}$ \\
\hline
\end{tabular}

Berdasarkan Gambar 2 terlihat bahwa kriteria yang memiliki nilai bobot tertinggi adalah potensi pasar dan kelestarian lingkungan. Hal tersebut menunjukkan bahwa potensi pasar produk agroindustri manggis dan kelestarian lingkungan dalam memproduksi produk agroindustri manggis dipandang oleh para ahli sebagai prasyarat penting dalam pengembangan agroindustri manggis. Hal tersebut sesuai dengan hasil penelitian Muchtaridi dkk., (2019) yang menyatakan bahwa 60\% masyarakat mengkhawatirkan masalah pengolahan 
limbah pada pembangunan agroindustri manggis di Kecamatan Puspahiang Kabupaten Tasikmalaya.

Selanjutnya pakar menilai produk agroindustri manggis berdasarkan kriteria penting. Penilaian dilakukan dengan menggunakan skala 1 (kurang baik) - 10 (sangat baik). Semakin baik nilai produk agroindustri manggis maka semakin tinggi skor. Hasil Perbandingan Ekponensial (MPE) untuk menentukan prioritas pengembangan produk agroindustri manggis di Kabupaten Tasikmalaya. Hasil analisis MPE secara lebih rinci dapat dilihat pada Tabel 3.

Tabel 4. Hasil analisis Matriks Internal Strategic Factors Analysis Summary (IFAS) dan External Strategic Factors Analysis Summary(EFAS).

\begin{tabular}{|c|c|c|c|}
\hline Faktor Internal & Bobot & Rating & Skor \\
\hline \multicolumn{4}{|l|}{ Kekuatan } \\
\hline 1 Ketersediaan pasar & 0,14 & 3,67 & 0,52 \\
\hline 2 Ketersediaan bahan baku & 0,14 & 4,00 & 0,56 \\
\hline 3 Dukungan kebijakan pemerintah & 0,11 & 2,33 & 0,26 \\
\hline 4 Ketersediaan sumberdaya manusia & 0,11 & 3,00 & 0,33 \\
\hline \multicolumn{4}{|l|}{ Kelemahan } \\
\hline 1 Isu lingkungan (pencemaran limbah agroindustri manggis) & 0,11 & 3,33 & 0,35 \\
\hline 2 Penguasaan teknologi proses & 0,13 & 2,67 & 0,35 \\
\hline 3 Kemampuan manajerial dan entrepreneurship & 0,13 & 3,00 & 0,39 \\
\hline $4 \quad$ Keterbatasan modal & 0,13 & 2,67 & 0,35 \\
\hline Total Skor Faktor Kekuatan dan Kelemahan & 1,00 & 24,67 & 3,11 \\
\hline \multicolumn{4}{|l|}{ Faktor Eksternal } \\
\hline \multicolumn{4}{|l|}{ Peluang } \\
\hline 1 Peningkatan nilai tambah & 0,13 & 3,00 & 0,39 \\
\hline 2 Penyerapan tenaga kerja dan peningkatan taraf hidup & 0,13 & 3,00 & 0,39 \\
\hline 3 Perkembangan teknologi informasi & 0,11 & 2,00 & 0,21 \\
\hline 4 Kemitraan usaha & 0,13 & 2,67 & 0,35 \\
\hline \multicolumn{4}{|l|}{ Ancaman } \\
\hline $\begin{array}{l}1 \text { Perubahan iklim berimplikasi pada produktivitas panen buah } \\
\text { manggis }\end{array}$ & 0,11 & 2,33 & 0,26 \\
\hline 2 Persaingan pasar dengan produk sejenis & 0,14 & 3,33 & 0,47 \\
\hline $\begin{array}{l}3 \text { Persaingan memperebutkan buah manggis dengan eksportir, dan } \\
\text { pedagang buah }\end{array}$ & 0,14 & 3,67 & 0,52 \\
\hline 4 Kondisi ekonomi nasional yang kurang stabil & 0,11 & 3,33 & 0,37 \\
\hline Total Skor Faktor Peluang dan Ancaman & 1,00 & 23,33 & 2,95 \\
\hline
\end{tabular}

Berdasarkan Tabel 3 terlihat bahwa prioritas utama pengembangan produk agroindustri manggis di Kabupaten Tasikmalaya yaitu ekstrak kulit manggis. Hal ini karena secara umum kulit manggis di Kabupaten Tasikmalaya dan sekitarnya hanya dibuang dan belum dimanfaatkan. Pengolahan kulit manggis menjadi ekstrak kulit manggis akan memberikan nilai tambah yang paling tinggi dibandingkan dengan produk olahan manggis lainnya yaitu sebesar $\quad$ Rp. 90.833/kg (Oryzanti et al, 2019) bahkan nilai tambah yang diberikan ekstrak kulit manggis dapat mencapai Rp. $153.723 / \mathrm{kg}$ (Narakusuma dkk., 2013). Konsep pengembangan kawasan agropolitan berbasis agroindustri ekstrak kulit manggis adalah solusi untuk menciptakan nilai tambah yang tinggi dan untuk meningkatkan pendapatan masyarakat di daerah tersebut. Hasil analisis kelayakan menunjukkan bahwa produk agroindustri kapsul dari kulit manggis memiliki peluang lebih besar untuk menarik minat investor karena layak dengan nilai NPV Rp17.690.067.855 (Oryzanti et al, 2019). Namun demikian, pembangunan agroindustri manggis harus bersifat terpadu, yaitu kulit manggis diolah menjadi ekstrak kulit manggis, buah manggis diolah manjadi sari buah manggis dan biji manggis diolah menjadi dodol biji manggis.

Minuman sari buah manggis dengan perlakuan ekstraksi menggunakan blender dan perlakuan pendahuluan kukus menghasilkan produk 
dengan nilai $\mathrm{pH} 4,24$, total padatan terlarut $7,54^{\circ}$ Brix, vitamin A 117,67 $\mu \mathrm{g} / 100 \mathrm{~g}$, kadar air 92,14\%, kadar abu $0,10 \%$, karbohidrat $7,30 \%$, protein $0,18 \%$, serat pangan $2,21 \%$, dan energi total sebesar 32,44 kkal (Novianti dkk. 2019). Produk olahan dodol juga memiliki potensi pasar yang cukup bagus terutama untuk pasar dalam negeri. Kebiasaan masyarakat Indonesia yang menjadikan dodol sebagai konsumsi untuk cemilan dan oleh oleh atau buah tangan membuat pasar dodol semakin luas. Dodol biji manggis memiliki nilai tambah yang tinggi, akan tetapi ia memiliki kelemahan karena peran manggis disini hanya sebagai bahan tambahan saja yaitu berupa biji yang dicampurkan dengan bahan utama yaitu tepung ketan. Kelebihannya ialah biji yang dimanfaatkan berupa hasil limbah dari sortiran manggis yang tidak laku atau rusak, kemudian biji tersebut diambil dan dimanfaatkan kembali sebagai bahan tambahan dodol manggis. Namun demikian, dodol biji manggis memiliki keunikan tersendiri karena rasa biji manggis yang mirip dengan rasa kenari. Proses pembuatan dodol biji manggis juga cukup sederhana (Narakusuma dkk., 2013).

\section{Strategi alternatif pengembangan agroindustri manggis}

Penyusunan strategi pengembangan agroindustri manggis dilakukan menggunakan analisis matriks Internal Strategic Factors Analysis Summary (IFAS) dan External Strategic Factors Analysis Summary (EFAS) berpengaruh dalam pengembangan agroindustri manggis. Penilaian pengaruh dari masing masing faktor internal dan eksternal didasarkan pada penilaian kepentingan, dengan nilai masing -masing kriteria $1-4$. Skala penilaian kriteria sebagai berikut: (1) sangat lemah, (2) Agak lamah, (3) Agak Kuat, (4) Sangat kuat. Hasil perkalian bobot dan Rating dari masing-masing faktor akan menjadi skor akumulasi dari faktor internal yang akan digunakan pada analisis matrik internal eksternal. Hasil analisis matrik IFA dan EFAS secara lebih rinci dapat dilihat pada Tabel 4.

Berdasarkan Tabel 4 diketahui bahwa skor total faktor kekuatan dan kelemahan adalah 3,11 sedangkan skor total faktor peluang dan ancaman adalah 2,95 sehingga diperoleh pemetaan faktor internal eksternal pada matrik dapat dilihat pada Gambar 3. Berdasarkan Gambar 3 matriks InternalEksternal dapat diketahui bahwa pengembangan agroindustri manggis di Kabupaten Tasikmalaya berada pada sel 2. Hal ini berarti perencanaan pengembangan komoditas unggulan yang harus diimplementasikan di Kabupaten Tasikmalaya adalah growth strategy dengan konsentrasi melalui integrasi horizontal. Strategi ini bertujuan memperluas usaha dengan cara meningkatkan jumlah produksi dan memperluas pasar dengan cara promosi (Arianti \& Waluyati, 2019). Strategi lain yang dapat dilakukan meliputi penetrasi pasar, pengembangan pasar, dan pegembangan produk (David, 2009). Integrasi horisontal pada sektor agribisnis dapat meningkatkan daya saing (Pawlak et al. 2019). Integrasi horizontal dapat dilakukan dengan menambah unit bisnis strategis yang dimiliki yang menghasilkan produk yang sama dengan yang dimiliki sebelumnya (Sumantra, et al. 2019).

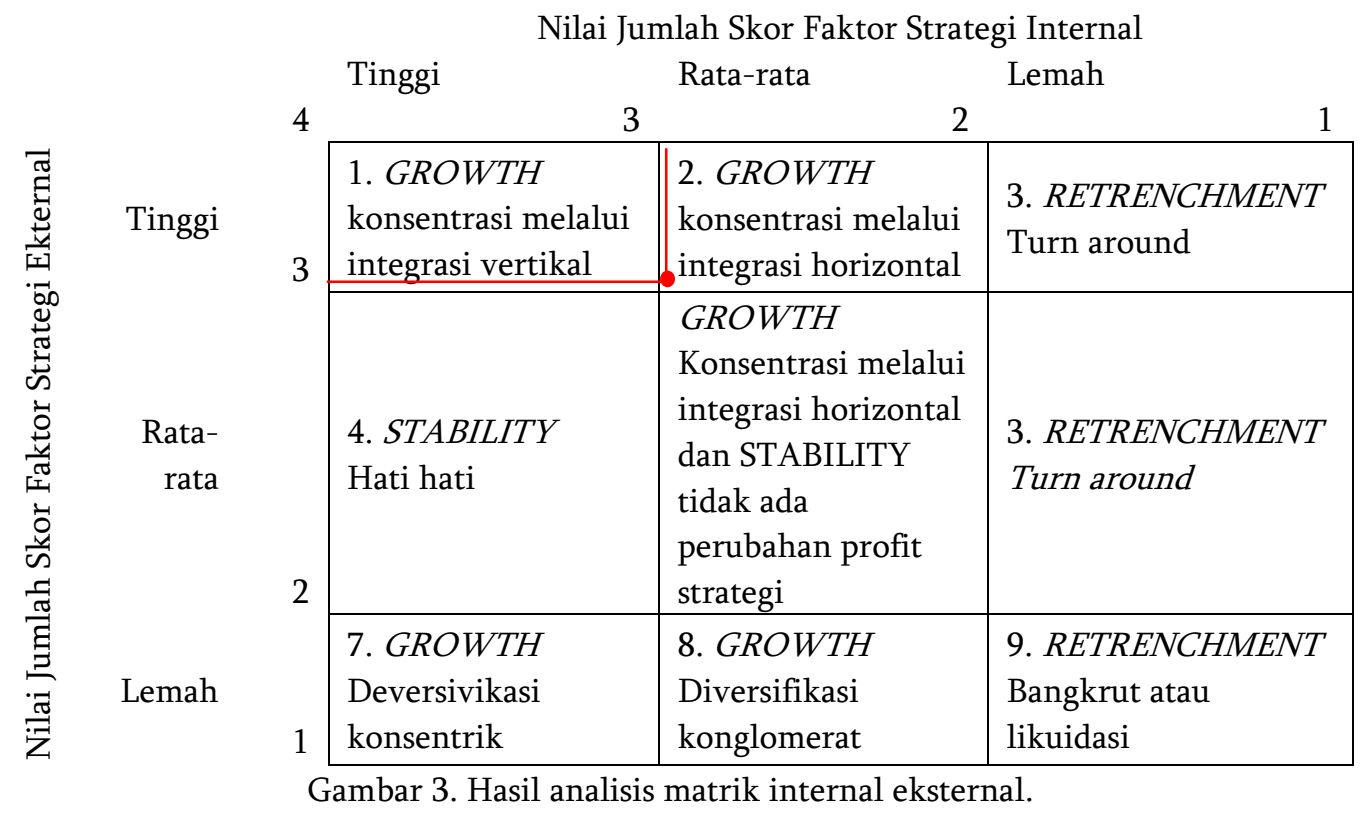


Upaya untuk mempertajam perencanaan pengembangan agroindustri manggis di Kabupaten Tasikmalaya dillakukan dengan menggunakan analisis matriks space. Analisis matriks space memberikan informasi tentang perpaduan faktor internal dan eksternal yang berada pada kuadran dari matriks space yang dibuat. Menurut Rangkuti (2015), matriks space digunakan untuk mempertajam posisi dan arah pengembangan dari analisis matriks internal dan eksternal. Marimin (2010) menyatakan bahwa, hasil analisis matriks
IFAS dan EFAS dapat digunakan untuk mengetahui posisi suatu usaha dalam matriks space. Selisih skor kekuatan dan kelemahan pada matriks IFAS dan selisih skor peluang dan ancaman pada matriks EFAS akan mengisi posisi nilai $\mathrm{x}$ dan $\mathrm{y}$ dari kuadran di matriks space nya. Berdasarkan analisis IFAS dan EFAS, maka diperoleh selisih skor kekuatan dan kelemahan pada matriks IFAS yaitu 0,23 dan selisih skor peluang dan ancaman pada matriks EFAS -0,27 Kombinasi nilai ini akan menghasilkan posisi dikuadran II seperti pada Gambar 4.



Berbagai Ancaman

Gambar 4. Hasil analisis matriks space.

Berdasarkan Gambar 4, maka diketahui posisi pengembangan agroindustri manggis di Kabupaten Tasikmalaya berada pada kuadran II yang menunjukkan wilayah tersebut menghadapi berbagai ancaman, namun masih mempunyai kekuatan sehingga strategi yang diterapkan adalah menggunakan kekuatan untuk memanfaatkan peluang jangka panjang dengan menerapkan strategi diversifikasi.

Pada tahap pengambilan keputusan, matriks SWOT perlu merujuk kembali kepada matriks IFAS dan matriks EFAS yang sudah dihasilkan. Dengan demikian dapat diketahui posisi suatu usaha berada pada sel mana dari matriks Internal Eksternal dan berada pada kuadran mana dari matriks space (Marimin, 2010). Jika merujuk hasil analisis matriks Internal Eksternal maka berada pada sel 2, dan berdasarkan analisis matriks space maka pengembangan komoditas unggulan di Kabupaten Tasikmalaya berada pada kuadran II. Dengan demikian, strategi yang akan digunakan dalam matriks SWOT menggunakan strategi ST (StrengthsThreats) sebagai strategi utama yaitu strategi yang dibuat dengan memanfaatkan seluruh kekuatan untuk mengeliminir ancaman sebesarbesarnya bagi pengembangan komoditas unggulan di
Kabupaten Tasikmalaya. Jika merujuk hasil analisis matriks Internal Eksternal maka berada pada sel 2, dan berdasarkan analisis matriks space maka pengembangan agroindustri manggis di Kabupaten Tasikmalaya berada pada kuadran II Dengan demikian, strategi yang akan digunakan dalam matriks SWOT adalah strategi ST (StrengthsThreats) sebagai strategi utama yaitu strategi yang dibuat dengan memanfaatkan seluruh kekuatan untuk mengeliminir ancaman sebesar-besarnya bagi pengembangan agroindustri manggis di Kabupaten Tasikmalaya yaitu:

1. Melakukan peningkatan kualitas produk melalui penerapan Good Manufacturing Practice (GMP) dan Cleaner Production (S1,T2)

2. Melakukan branding produk dan memperkuat promosi melalui iklan TV, sosial media, pameran produk atau misi dagang yang diselenggarakan pemerintah/swasta $(\mathrm{S} 1, \mathrm{~T} 2)$

3. Melakukan pengembangan dan inovasi produk $(\mathrm{S} 1, \mathrm{~T} 2)$

4. Meningkatkan harga beli buah manggis ditingkat petani melalui kontrak kerjasama kemitraan $(\mathrm{S} 2, \mathrm{~T} 3)$ 
5. Menciptakan bibit unggul yang mampu adaptif terhadap lingkungan melalui pengembangan bibit unggul lokal (S2,T1)

6. Melakukan peningkatan kualitas SDM melalui pelatihan dan studi banding didalam/diluar negeri $(\mathrm{S} 3, \mathrm{~S} 4, \mathrm{~T} 4)$

7. Melakukan peningkatan kesejahteraan petani melalui integrasi dengan ternak lebah madu $(\mathrm{S} 3, \mathrm{~S} 4, \mathrm{~T} 4)$

\section{Prioritas strategi pengembangan agroindustri manggis \\ Penentuan prioritas pengembangan} agroindustri manggis dilakukan menggunakan metode Analytical Network Process (ANP). Kerangka Analytical Network Process (ANP) yang terdiri atas empat klaster yaitu tujuan, faktor, aktor dan alternative strategi (Qurratu'ain, 2017; Kasutjianingati, et al. 2019). Berdasarkan. Berdasarkan diskusi dan wawancara dengan beberapa pakar tujuan pengembangan agroindustri manggis adalah 1) meningkatkan nilai tambah produk, 2) meningkatkan pendapatan asli daerah (PAD), 3) penyedia lapangan kerja, 4) meningkatakan kesejahteraan masyarakat, dan 5) meningkatkan perolehan devisa dan kontribusi terhadap produk domestik bruto (PDB) nasional.

Faktor penting dalam pengembangan agroindustri manggis diantaranya: 1) pasar, 2) kelestarian lingkungan, 3) bahan baku, 4) dukungan pemerintah daerah, 5) sumber daya manusia, 6) teknologi, 7) kemampuan bersaing produk sejenis, dan 8) modal usaha. Aktor yang berperan dalam pengembangan adalah: 1) petani, 2) pengusaha (pengumpul/pedagang/eksportir), 3) pemerintah, dan 4) akademisi/peneliti. Sementara itu, strategi alternatif adalah hasil analisis SWOT. Struktur ANP dan hasil penilaian pakar secara lebih rinci dapat dilihat pada Gambar 5.

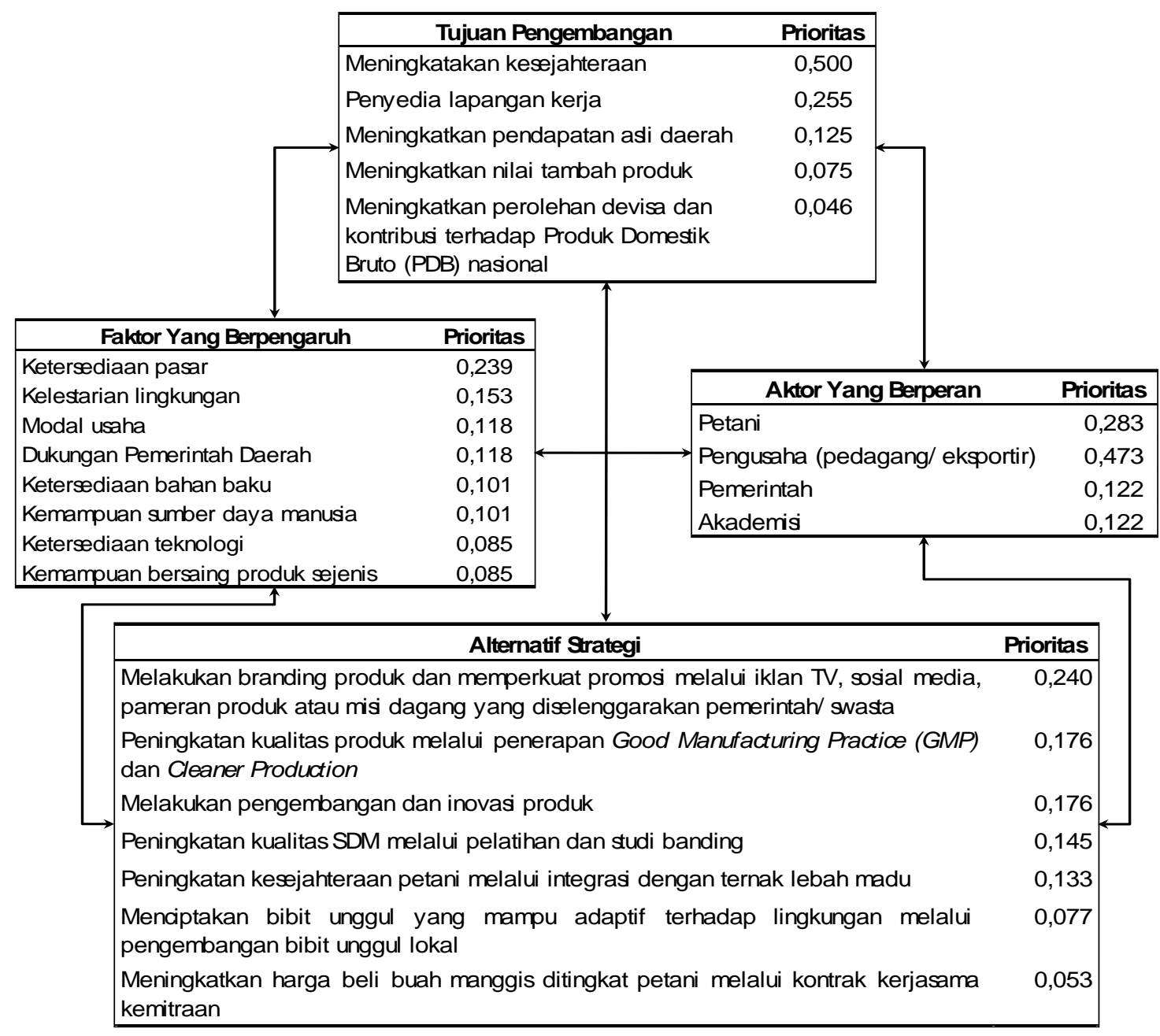

Gambar 2. ANP struktur of manggosteen agroindustry development strategy. 


\section{SIMPULAN}

Berdasarkan hasil analisis Location Quotient (LQ) and Differential Shift (DS) diketahui bahwa lokasi potensial komoditas manggis terdapat pada empat kecamatan di Kabupaten Tasikmalaya yaitu Kecamatan Sodonghilir, Kecamatan Tanjungjaya, Kecamatan Sukaraja, dan Kecamatan Jatiwaras. Prioritas pengembangan produk agroindustri manggis berdasarkan analisis metode perbandingan ekponensial secara berurutan adalah ekstrak kulit manggis $(9,63)$, sari buah/ jus manggis $(9,56)$, sirup buah manggis $(9,53)$, buah kaleng manggis $(9,51)$, puree manggis $(9,50)$, es krim kulis manggis $(9,48)$, dodol biji manggis $(9,47)$, dan tepung kulit manggis $(9,45)$.

Prioritas strategi pengembangan agroindustri manggis bagi petani, yakni: 1) Branding dan promosi produk melalui iklan TV, sosial media, pameran produk atau misi dagang yang diselenggarakan pemerintah/swasta, 2) Peningkatan kualitas produk melalui penerapan Good Manufacturing Practice (GMP) dan Cleaner Production, 3) Pengembangan dan inovasi produk, 4) Peningkatan kualitas sumber daya manusia, antara lain melalui pelatihan dan studi banding, 5) Peningkatan kesejahteraan petani, misalnya melalui integrasi dengan ternak lebah madu 6) Bibit unggul yang mampu adaptif terhadap lingkungan, misalnya dengan pengembangan pertanaman manggis dengan ternak lebah madu, serta 7) Peningkatan harga jual buah manggis, misalnya dengan adanya kerjasama kemitraan.

\section{UCAPAN TERIMAKASIH}

Ucapan terima kasih disampaikan kepada: 1)

Badan Perencanaan Pembangunan Daerah Kabupaten Tasikmalaya atas kontribusi biaya penelitian ini, dan 2) Pakar yang berasal dari beberapa instansi Pemerintah Daerah Kabupaten Tasikmalaya atas kontribusi waktu dalam penyelesaian penelitian ini.

\section{DAFTAR PUSTAKA}

Arianti, YS, dan LR Waluyati. 2019. Analisis nilai tambah dan strategi pengembangan agroindustri gula merah di Kabupaten Madiun. Jurnal Ekonomi Pertanian dan Agribisnis (JEPA). 3(2): 256-266.

[BPS] Badan Pusat Statistik. 2019. Statistik Tanaman Buah-buahan dan Sayuran Tahunan
Indonesia 2018. Badan Pusat Statistik. Jakarta.

[BPS] Badan Pusat Statistik Kabupaten Tasikmalaya. 2020. Kabupaten Tasikmalaya Dalam Angka 2020. Badan Pusat Statistik Kabupaten Tasikmalaya.

[BPS] Badan Pusat Statistik dan Direktorat Jenderal Hortikultura. 2020. Produksi Manggis Menurut Provinsi, Tahun 2015-2019. Tersedia online pada: https://www.pertanian.go.id. Diakses tanggal 5 Juni 2020.

[BI] Bank Indonesia. 2019. Laporan Perekonomian Indonesia 2018. Bank Indonesia. Jakarta.

David, FR. 2009. Manajemen Strategis. Penerbit Salemba Empat. Jakarta.

Hendayana, R. 2003. Aplikasi metode Location Quotient (LQ) dalam penentuan komoditas unggulan nasional. Jurnal Informatika Pertanian. 12(1): 1-21.

Hidayati, S, TP Utomo, E Suroso, and A Maktub. 2019. Technical and technology aspect assessment of biogas agroindustry from cow manure: case study on cattle livestock industry in South Lampung District. International Conference on Green Agroindustry and Bioeconomy IOP Conf. Series: Earth and Environmental Science 230 (2019) 012072 IOP Publishing doi:10.1088/17551315/230/1/012072 1.

Jakiyah, U, dan Sukmaya. 2020. Efisiensi pemasaran komoditas manggis di Kabupetan Tasikmalaya. Mimbar Agribisnis: Jurnal Pemikiran Masyarakat Ilmiah Berwawasan Agribisnis. 6(1): 201-212.

Kasutjianingati, A Wahyono, A Brilliantina, and EK Novitasari. 2019. SWOT and Analytical Network Process (ANP) analysis for robusta coffee bean development strategy in Panti District Jember Regency. Second International Conference on Food and Agriculture 2019. IOP Conf. Series: Earth and Environmental Science 411 (2020) 012019 IOP Publishing doi:10.1088/17551315/411/1/012019.

Keratorop, M, Widiatmaka, dan Suwardi. 2016. Arahan pengembangan komoditas tanaman pangan di Kabupaten Boven Digoel Provinsi Papua. Jurnal Pengelolaan Sumberdaya Alam dan Lingkungan. 6(2): 141-150. 
Marimin. 2010. Teknik dan Aplikasi Pengambilan Keputusan Kriteria Majemuk. PT. Gramedia Widiasarana Indonesia. Jakarta.

Mulya, SP, INDM Hikmah, HWidjaja, and Widiatmaka. 2019. Multi-criteria analysis for determining primary commodities at Jasinga District, Bogor Regency, Indonesia. IOP Conf. Series: Earth and Environmental Science 399 (2019) 012072 IOP Publishing, doi:10.1088/1755-1315/399/1/012072.

Muchtaridi, W Nurhidayah, LU Setyawati, D Rochdiani, RR Islamiaty, dan A Budiman. 2019. Pendekatan sosio-ekonomi potensi daerah sebagai pusat ekstrak kulit manggis di Indonesia. Jurnal Pengabdian Kepada Masyarakat. 4(2): 179-188.

Namugenyi, C, SL Nimmagadda, and T Reiners. 2019. Design of a SWOT analysis model and its evaluation in diverse digital business ecosystem contexts. Procedia Computer Science. 159: 1145-1154.

Narakusuma, MA, AM Fauzi, dan M Firdaus. 2013. Rantai Nilai Produk Olahan Buah Manggis. Jurnal Manajemen \& Agribisnis. 10(1): 1121.

Novianti, ND, AR Audina, DA Kurniasari, Rohmah, R Luthfiyanti, dan L Dzulfiah. 2019. Pengaruh perlakuan pendahuluan dan perbedaan tipe ekstraksi terhadap mutu produk minuman sari buah manggis. Industria: Jurnal Teknologi dan Manajemen Agroindustri. 8(2): 154-164.

Nowar, W, DPT Baskoro, dan B Tjahjono. 2015. Analisis kesesuaian lahan komoditas unggulan dan arahan pengembangannya di wilayah Kabupaten Cianjur. Jurnal Tata Loka. 17(2): 87-98.

Oryzanti, P, E Rustiadi, Eriyatno, and NT Rochman. 2019. Economic development of mangosteen agro-industry based on sustainability. Journal of Economics and Policy. 12(1): 33-53.

Pawlak, K, M Kolodziejczak, and Y Xie. 2019. Horizontal integration in the agricultural sector as a factor increasing its competitiveness - experience from Poland. Eastern European Countryside. 25(1): 195232.

Purba, J. 2017. Analisis Komoditas Unggulan dan Arahan Rencana Serta Strategi Pengembangannya di Kabupaten Pakpak Barat Provinsi Sumatera Utara. [Tesis]. Sekolah Pascasarjana Institut Pertanian Bogor. Bogor.

Qurratu'ain, DA. 2017. Strategi Promosi Produk Asuransi Perjalanan Pada PT XYZ. [Skripsi]. Fakultas Ekonomi dan Manajemen, Institut Pertanian Bogor. Bogor.

Rangkuti, F. 2015. Analisis SWOT Teknik Membedah Kasus Bisnis. PT. Gramedia Pustaka Utama. Jakarta.

Sitorus, SRP, BW Widodo, dan DR Penuju. 2013. Identifikasi komoditas basis tanaman pangan dan arahan pengembangannya di Provinsi Lampung. Jurnal Tanah Lingkungan. 15(1): 29-38.

Sumantra, K, K Suryani, IW Widyana, CC Menes, IBP Sutrisna, Oktarina, and RS Dana. 2019. Swot Analysis of Village Owned Enterprises (Bumdes) Trading Business of "Ayu Bagia" Goods in Baha Village - Kecamatan Mengwi Badung District-Bali. IJSEGCE. 2(1): 15-20.

Wulan, AJ. 2015. Buah manggis (Garcinia mangostana L.) sebagai alternatif pelindung memori. Prosiding Seminar Presentasi Artikel Ilmiah Dies Natalis Fakultas Kedokteran Universitas Lampung Ke-13. Bandar Lampung. Oktober 2015. Hlm. 58-63.

Yuarini, DAA, dan LP Wrasiati. 2015. Aktivitas antioksidan dan senyawa bioaktif yang terkandung dalam minuman fungsional dari ekstrak kulit manggis dan rosela. Media Ilmiah Teknologi Pangan. 2(1): 69-77.

Yulianti, E, dan F Juwita. 2016. Sistem pendukung keputusan pemilihan tempat kuliner di Kota Padang menggunakan Metode Perbandingan Eksponensial (MPE). Jurnal Teknoif. 4(2): 51-58. 